Arch. Histol. Cytol., Vol. 61, No. 2 (1998)

p. $99-113$

\title{
Immunocytochemical Localization of Chromogranin A and Secretogranin II in Female Rat Gonadotropes*
}

\author{
Tsuyoshi Watanabe ${ }^{1}$, Takahiro Azuma ${ }^{2}$, Tomohiro Banno ${ }^{2 * *}$, Thomas Jezionowski ${ }^{3 * * *}$, \\ Yoshiyuki OHSAWA ${ }^{1}$, Satoshi WAGURI ${ }^{1}$, Dietrich GRUBE ${ }^{3}$ and Yasuo UCHIYAMA ${ }^{1}$
}

Department of Cell Biology and Anatomy $\mathrm{I}^{1}$, Osaka University Medical School, Osaka; Department of Anatomy ${ }^{2}$. Institute of Basic Medical Sciences, University of Tsukuba, Tsukuba, Japan; and Department of Anatomy I ${ }^{3}$, Hannover Medical School, Hannover, FRG

Received February 3, 1998

\begin{abstract}
Summary. Ultrastructures of pituitary gonadotropes are known to show a prominent sex-related difference: typical male rat gonadotropes contain both large- and small-sized granules, whereas typical female rat gonadotropes appear to exhibit uniformly small-sized granules. Our preceding studies have demonstrated that two representative granins, chromogranin $\mathrm{A}(\mathrm{CgA})$ and secretogranin II (SgII), are separately localized to each type of granule in male rat gonadotropes. To clarify whether or not there is a certain relationship between granin proteins and characteristic features of secretory granules in female rat gonadotropes, we examined the expression levels and immunocytochemical localizations of $\mathrm{CgA}$ and $\mathrm{SgII}$ in the cells. Northern blot and immunoblot analyses demonstrated that both $\operatorname{CgA}$ and SgII were synthesized and stored in the female pituitary, although the amount of $\mathrm{CgA}$ was much lower in the female than that in the male pituitary. Immunocytochemical observations clarified that gonadotropes in the female pituitary possessed intermediate secretory granules containing both $\mathrm{CgA}$ and $\mathrm{SgII}$, in addition to solely $\mathrm{CgA}$-positive and SgII-positive ones. However, secretory granules containing $\mathrm{CgA}$ in the female gonadotropes were much smaller in size and appeared less frequently than those in the male cells, whereas no sexual difference was discerned in SgII-positive granules. Moreover, the size and appearance of $\mathrm{CgA}$-positive secretory granules varied depending on stages of the estrous cycle. These findings suggest that the size and appearance of secretory granules containing $\mathrm{CgA}$ are closely associated with the expression and storage levels of $\mathrm{CgA}$ in the pituitary.
\end{abstract}

Two gonadotropins, follicle-stimulating hormone (FSH) and luteinizing hormone (LH), are synthesized in the anterior lobe of the pituitary gland, and cooperatively regulate reproductive functions in both male and female animals. Investigations using immunohistochemistry and in situ hybridization have demonstrated that a single cell type called gonadotropes can potentially synthesize and secrete both pituitary gonadotropins (CHILDS 1986; CHILDS et al., 1987a, b; LIU et al., 1988). These two gonadotropins, however, are not always secreted in a parallel manner, suggesting that their secretory systems in the cells may differ from each other by having different secretory granules (CHILDS et al., 1987a, b; LLOYD and CHILDS, 1988: RIVIER et al., 1991; for review see also FARN. WORTH, 1995).

Ultrastructurally, typical male rat gonadotropes possess two types of secretory granules which can be easily distinguished by conventional electron microscopy: one of these granules is small-sized and electron-dense, and the other is large-sized and less electron-dense (CHILDS, 1986; KUROSUMI et al., 1991; WATANABE et al., 1991; TOUGARD and TIXIERVIDAL, 1994). Although the localization of gonadotropins in gonadotropes remains undefined, our preceding studies have demonstrated that chromogranin $\mathrm{A}(\mathrm{CgA})$ and secretogranin II (SgII), two different secretory proteins which belong to the granin protein family, are localized separately in

\footnotetext{
${ }^{*}$ This work was supported by a Grant-in Aid for Scientific Research from the Ministry of Education, Sciences and Culture, Japan.

**The current address of T. B.: the Department of Dermatology, Institute of Clinical Medicine, University of Tsukuba, 305 Tsukuba, Japan.

***The current address of T. J.: the Department of Anatomy II, Faculty of Medicine, Ludwig Maximilians University, D-80336 Munich, FRG.
} 
these two types of secretory granules; $\mathrm{CgA}$ is restrictively localized to the large-sized secretory granules, whereas SgII is confined to the small-sized ones (WATANABE et al., 1991, 1993; JEZIOROWSKI et al., 1997). These findings suggest that $\mathrm{CgA}$ and SgII are potentially useful markers for tracing the different matrices of secretory granules within male rat gonadotropes.

In contrast to the male rat gonadotropes, smallsized secretory granules predominate in the typical female rat gonadotropes, while large-sized secretory granules are scarce in them (CHILDS, 1986; KUROSUMI et al., 1991; TOUGARD and TIXIER-VIDAL, 1994). To date, there has been no study on the intracellular localization of $\mathrm{CgA}$ and $\mathrm{SgII}$ in female rat gonadotropes. As stated above, these granin proteins show a different localization in the two subsets of secretory granules in male rat gonadotropes. Therefore, to further understand the characteristics of secretory granules in female rat gonadotropes with a homogeneous appearance in size and texture, it may be important to analyze the localization patterns of $\mathrm{CgA}$ and $\mathrm{SgII}$.

To clarify whether the heterogeneity of secretory granules in content is present within female rat gonadotropes, we examined the expression levels and the immunocytochemical localization of $\mathrm{CgA}$ and SgII in the cells. From the results of the present and preceding studies, we summarize both the common features and sex-related differences of secretory granules in male and female gonadotropes, and discuss the putative roles of $\mathrm{CgA}$ and SgII in maintaining the secretory pathways within gonadotropes.

\section{MATERIALS AND METHODS}

\section{Animals}

Eighty female and thirteen male Wistar rats (10 weeks of age) were used for the present study. They were housed in plastic cages placed in a well-ventilated room (temperature $23 \pm 1^{\circ} \mathrm{C}$; relative humidity $55-65 \%$ ) with food and water ad libitum. The lighting condition was defined as a 12:12-hour dark-light cycle (light period: 0700h-1900h).

Daily vaginal lavages of the female rats were obtained, and only those rats which exhibited two or more consecutive 4-day estrous cycles were used for the following experiments.

\section{Tissue and blood plasma preparations for biochemical analyses}

Tissue and blood samples for biochemical analyses were taken from synchronized female rats $(n=5$ per each time point) at the following time points: at 0800 $\mathrm{h}$ of the second day of diestrus (designated as $\mathrm{DII}_{0800}$ ), $0800 \mathrm{~h}, 1600 \mathrm{~h}, 1800 \mathrm{~h}, 2000 \mathrm{~h}$, and $2200 \mathrm{~h}$ of the proestrus $\left(\mathrm{P}_{0800}, \mathrm{P}_{1600}, \mathrm{P}_{1800}, \mathrm{P}_{2000}\right.$, and $\mathrm{P}_{2200}$, respectively), and $0000 \mathrm{~h}$ and $0800 \mathrm{~h}$ of the estrus $\left(\mathrm{E}_{0000}\right.$ and $\left.\mathrm{E}_{0800}\right)$. As a control, these samples were also taken from male rats $(n=5)$ at $0800 \mathrm{~h}$ in the same way.

Blood was collected into tubes containing heparin (100 units per tube) by puncture of the abdominal aorta under anesthesia with pentobarbital $(25 \mathrm{mg} /$ $\mathrm{kg}$; i. p.). The blood samples were then centrifuged at $4^{\circ} \mathrm{C}$ for $10 \mathrm{~min}$, and the plasma of each sample was divided into aliquots and stored at $-70^{\circ} \mathrm{C}$ until assay.

For northern blot and immunoblot analyses, pituitaries and adrenals were excised from the same animals immediately after blood sampling. Tissue samples were then quickly frozen in liquid nitrogen and stored at $-70^{\circ} \mathrm{C}$ until use:

\section{Radioimmunoassay}

Plasma concentrations of LH and FSH were assayed using commercially available radioimmunoassay kits (rat luteinizing hormone (rLH) [ $\left.{ }^{125} \mathrm{I}\right]$ assay system (code: RPA 552) and rat follicle stimulating hormone (rFSH) $\left.{ }^{125} \mathrm{I}\right]$ assay system (code: RPA 550); Amersham Intl., Little Chalfont, England) according to kit instructions. Briefly, $100 \mu \mathrm{l}$ of plasma samples were mixed with $100 \mu$ l of rabbit antiserum (anti-rat LH or anti-rat FSH serum) and $100 \mu 1$ of tracer $\left(\left[{ }^{125} \mathrm{I}\right]\right.$ rat $\mathrm{LH}$ or $\left[{ }^{125} \mathrm{I}\right]$ rat $\mathrm{FSH}$; ca. $13,000 \mathrm{cpm}$ per assay tube), and incubated for $16 \mathrm{~h}$ at room temperature. All reagents and samples were dissolved and diluted with the assay buffer $(0.025 \mathrm{M}$ phosphate buffer, $\mathrm{pH} 7.5$, containing $0.1 \%$ sodium azide) included in the kit. Free and bound fractions of the radiolabeled tracer were separated by the addition of $400 \mu$ l of Amerlex$\mathrm{M}$ second antibody reagent (Amersham Intl.), and after centrifugation for $10 \mathrm{~min}$ at $1,500 \mathrm{~g}$, the radioactivity in the precipitate was measured in a gamma scintillation counter. The amount of LH or FSH in the sample was read from a standard curve, and expressed in ng of the standard preparation of rat LH or FSH provided by the supplier. The statistical analysis was performed by analysis of variance using Tukey's comparison test.

\section{Northern blot analysis}

Partial cDNA sequences of $\mathrm{CgA}$ and SgII were amplified from the rat pituitary poly $(\mathrm{A})^{+} \mathrm{RNA}$ by the RT-PCR technique, and a $1110 \mathrm{bp} c \mathrm{DNA}$ fragment of rat $\mathrm{CgA}$ (from position 40 of the nucleic acid sequence: IACANGELO et al., 1988) and a $693 \mathrm{bp}$ cDNA fragment of rat SgII (from position 1 of the nucleic acid sequence: GERDES et al., 1988) were obtained. 
These cDNA fragments were subcloned into the HindIII and Xhol sites of pcDNA3 vector (Invitrogen Corporation, San Diego, USA), and their sequences were determined and confirmed to be identical with the reported sequences of rat $\mathrm{CgA}$ or SgII.

Using these vectors inserted with $\mathrm{CgA}$ and $\mathrm{SgII}$ cDNA fragments as templates, digoxigenin-labeled single strand RNA probes were prepared. Digoxigenin-UTP-labeled sense and antisense RNA probes were prepared by using the DIG RNA Labeling Kit (Boehringer Mannheim GmbH Biochemica, Mannheim, Germany) according to the manufacturer's recommendations.

The total RNA of pituitary and adrenal glands from each rat was extracted according to the procedure by CHOMCZYNSKI and SACCHI (1987). Ten micrograms of the total RNA was separated on a $1.5 \%$ agarose formaldehyde denaturing gel (SAMBROOK et al., 1989). After the RNA was transferred to nylon membrane filters (GeneScreen Plus ${ }^{\circledR}$; DuPont-New England Nuclear Research Products, Boston, USA), the filters were baked for $2 \mathrm{~h}$ at $80^{\circ} \mathrm{C}$ and prehybridized for $4 \mathrm{~h}$ at $65^{\circ} \mathrm{C}$ in a hybridization solution containing $50 \%$ formamide, $5 \times \mathrm{SSPE}(\mathrm{pH}$ 7.4), $5 \times$ Denhardt's solution, $1 \%$ SDS, and 10\% sodium dextran sulfate (MW; 500,000). Hybridization proceeded at $65^{\circ} \mathrm{C}$ for $16 \mathrm{~h}$ in the same buffer with each containing a $100 \mathrm{ng} / \mathrm{ml}$ digoxigenin-11-UTP. labeled RNA probe. The filters were then washed in $2 \times \mathrm{SSC} / 0.1 \% \mathrm{SDS}$ for $10 \mathrm{~min}$ at $25^{\circ} \mathrm{C}, 0.2 \times \mathrm{SSC} / 0.1 \%$ SDS twice for $20 \mathrm{~min}$ at $65^{\circ} \mathrm{C}$. They were then washed briefly with TNE buffer $(10 \mathrm{mM}$ Tris- $\mathrm{HCl}, 500 \mathrm{mM}$ $\mathrm{NaCl}, 1 \mathrm{mM}$ EDTA, pH 7.5) and treated with RNase A $(20 \mu \mathrm{g} / \mathrm{ml})$ in the same buffer at $37^{\circ} \mathrm{C}$ for $20 \mathrm{~min}$. After washing with TNE to remove RNase, they were immersed in DIG buffer $1(100 \mathrm{mM}$ maleic acid, $150 \mathrm{mM} \mathrm{NaCl}, \mathrm{pH}$ 7.5) for $10 \mathrm{~min}$.

Immunodetection of each hybridized digoxigeninlabeled RNA probe was performed using a DIG Luminescent Detection Kit (Boehringer Mannheim $\mathrm{GmbH}$ Biochemica) with some modifications. The filters were incubated with $1.0 \%$ blocking reagent in DIG buffer 1 for $60 \mathrm{~min}$ at $25^{\circ} \mathrm{C}$, and further treated with 0.075 units $/ \mathrm{ml}$ of polyclonal sheep antidigoxigenin Fab fragments conjugated to alkaline phosphatase in DIG buffer 1 for $30 \mathrm{~min}$ at $25^{\circ} \mathrm{C}$. Excess antibody was removed by washing with DIG buffer 1 containing $0.2 \%$ Tween-20 twice for $15 \mathrm{~min}$. The washed filters were equilibrated for $5 \mathrm{~min}$ with DIG buffer $3(100 \mathrm{mM}$ Tris- $\mathrm{HCl}, 100 \mathrm{mM} \mathrm{NaCl}, 50 \mathrm{mM}$ $\mathrm{MgCl}_{2}, \mathrm{pH}$ 9.5) and assay buffer (100 mM diethanol amine, $2 \mathrm{mM} \mathrm{MgCl}_{2}$ ) for $3 \mathrm{~min}$, and then incubated in $0.1 \mathrm{mg} / \mathrm{ml}$ disodium 3-(4-methoxyspiro $\{1,2$-dioxetane-3, 2'-(5'-chloro) tricyclo [3.3.1.13,7] decan $\}$-4-yl) phenyl phosphate $\left(\mathrm{CSPD}^{\circledR}\right.$; Tropix inc., Bedford, $\left.\mathrm{MA}\right)$ in assay buffer for $10 \mathrm{~min}$ at $25^{\circ} \mathrm{C}$. After the excess substrate was removed, the filters were exposed to $\mathrm{x}$-ray film for $30 \mathrm{~min}$ and developed.

\section{Immunoblotting}

The pituitaries of animals were individually homogenized in $1 \mathrm{ml}$ of $0.05 \mathrm{M}$ Tris- $\mathrm{HCl}$ buffer $(\mathrm{pH} 7.0$ ), containing $0.15 \mathrm{M} \mathrm{NaCl}, 1 \%$ Triton X-100, $1 \mathrm{mM}$ EDTA, $10 \mathrm{mg} / \mathrm{ml}$ leupeptin (Peptide Institute Inc., Osaka, Japan), $10 \mathrm{mg} / \mathrm{ml}$ pepstatin (Peptide Institute Inc.), $0.05 \mathrm{mM}$ p-amidino-phenyl methanesulfonyl fluoride hydrochloride (WAKO Pure Chemicals), in a Polytron homogenizer (Kinematica $\mathrm{GmbH}$, Switzerland) at $80 \%$ of the maximal speed for $10 \mathrm{sec}$. Immediately after homogenization, samples were centrifuged at $10,500 \mathrm{~g}$ for $20 \mathrm{~min}$ at $4^{\circ} \mathrm{C}$, and the supernatants were then used for immunoblotting.

Extracts of pituitaries and adrenals (used as controls) were analyzed by $10 \%$ SDS-PAGE under reducing conditions. Electrophoretic transfer of proteins from the polyacrylamide gel to hydrophobic Durapore sheets (Immobilon-P ${ }^{\circledR}$; Millipore Limited Co., Tokyo, Japan) was performed according to the method by TowBIN et al. (1979). The sheets were soaked in PBS containing 5\% BSA (Sigma Chemical Co.) to block nonspecific binding, and then incubated with antisera directed against rat $\mathrm{CgA}$ or SgII (diluted 1:200). Immunodetection was carried out with a chemiluminescent ECL kit (Amersham Intl.) according to the manufacturer's recommended protocol.

\section{Tissue preparation for immunocytochemistry}

Pituitaries for morphological analyses were taken from synchronized female rats at the time points, $\mathrm{DII}_{0800}, \mathrm{P}_{0800}, \mathrm{P}_{1600}, \mathrm{E}_{0000}$ and $\mathrm{E}_{0800}$. As a control, samples were also taken from male rats at $0800 \mathrm{~h}$ in the same way.

For light microscopy, two rats at each time point were sacrificed by cervical dislocation under light ether anesthesia. The pituitaries were quickly removed, cut into small pieces, and quenched in liquid nitrogen at $-210^{\circ} \mathrm{C}$ (device according to Umrat; Leybold-Heraeus, Cologne, Germany). The specimens were freeze-dried at $-35^{\circ} \mathrm{C}$ for $72 \mathrm{~h}$, fixed by vapor phase di-ethylpyrocarbonate $\left(60^{\circ} \mathrm{C}, 3 \mathrm{~h}\right)$ and embedded in epoxy resin (Araldite). Serial sections were cut at $1 \mu \mathrm{m}$ and mounted on microscopic slides.

For routine electron microscopy, rats $(n=3$ per each time point) were anesthetized with pentobarbital $(25 \mathrm{mg} / \mathrm{kg}$; i. p.), perfused with $50 \mathrm{ml}$ of physiological saline, and then with $250 \mathrm{ml}$ of $2 \%$ glutaraldehyde- $2 \%$ paraformaldehyde in $0.1 \mathrm{M}$ phosphate buffer, pH 7.2. The pituitaries were quickly excised, 
cut into small pieces and immersed in the same fixative at $4^{\circ} \mathrm{C}$ for $24 \mathrm{~h}$. After washing thoroughly with $0.1 \mathrm{M}$ phosphate buffer, $\mathrm{pH} 7.2$, containing $7.5 \%$ sucrose, samples were postfixed with $1 \% \mathrm{OsO}_{4}$ in 0.1 $\mathrm{M}$ phosphate buffer containing $7.5 \%$ sucrose ( $\mathrm{pH} 7.2)$ at $4^{\circ} \mathrm{C}$ for $2 \mathrm{~h}$. The samples were then dehydrated using a graded series of ethanol and embedded in Epon 812.

For immuno-electron microscopy, rats $(n=3$ per each time point) were perfused with physiological saline and $4 \%$ paraformaldehyde in $0.1 \mathrm{M}$ phosphate buffer containing $4 \%$ sucrose $(\mathrm{pH} 7.2)$. After fixation by perfusion, the pituitaries were excised, cut into small pieces, dehydrated in graded ethanol, and embedded in Epon 812.

\section{Antisera}

Gonadotropes were identified with a polyclonal antiserum (rabbit origin) against ovine LH $\beta$-subunit (oLH $\beta$; generated by Dr. WAKABAYASHI, Gumma University, Japan). This antiserum (diluted 1:4,000) crossreacts slightly with rat TSH (1\%) and rat FSH $(0.3 \%)$ in radioimmunoassay (Dr. WAKABAYASHI; personal communication). Polyclonal antisera against rat chromogranin $\mathrm{A}(\mathrm{rCgA})$ and secretogranin II (rSgII) were generated by Dr. FISCHER-COLBRIE and Dr. WINKLER, University of Innsbruck, Austria, and characterized previously by immunoblotting and adequate immunocytochemical preadsorption tests (FISCHER-COLBRIE et al., 1984; GRUBE and YOSHIE, 1989; BARGSTEN and GRUBE, 1992).

\section{Immunocytochemistry}

For light microscopic immunocytochemistry, the semithin sections were treated with $0.3 \% \mathrm{H}_{2} \mathrm{O}_{2}\left(20^{\circ} \mathrm{C}, 30\right.$ $\mathrm{min}$ ) after removal of the resin by sodium methoxide (GRUBE and KUSUMOTO, 1986), incubated with $2 \%$ non-immune goat serum $\left(20^{\circ} \mathrm{C}, 30 \mathrm{~min}\right)$, and then incubated with anti- $\mathrm{LH} \beta$ (diluted 1: 50,000), anti-rCgA (diluted $1: 20,000$ ), or anti-rSgII (diluted $1: 20,000$ ) antisera for $24 \mathrm{~h}$ at $4^{\circ} \mathrm{C}$. They were subsequently incubated with biotinylated goat anti-rabbit IgG (Histofine SAB-PO kit; Nichirei, Tokyo, Japan) at room temperature for $20 \mathrm{~min}$, and then with peroxidase-conjugated streptavidin (Nichirei) at room temperature for $20 \mathrm{~min}$. Staining for peroxidase was performed using $0.7 \mathrm{mM} \mathrm{3'3'-diaminobenzidine} \mathrm{tetra-}$ hydrochloride (DAB) and $0.002 \% \mathrm{H}_{2} \mathrm{O}_{2}$ in $0.05 \mathrm{M}$ Tris- $\mathrm{HCl}$ buffer, $\mathrm{pH} 7.6$ for $10 \mathrm{~min}$. Between the various steps of the protocol, the sections were thoroughly rinsed in $0.01 \mathrm{M}$ phosphate buffered $0.5 \mathrm{M}$ saline, pH 7.6, containing 0.1\% Tween-20 (Sigma).

For immuno-electron microscopy, ultrathin sections from tissue blocks embedded in Epon 812 were cut with an ultramicrotome (Ultracut, Leica, Nußloch, Germany) and mounted on nickel grids. The sections were etched with $1 \%$ sodium methoxide for $30 \mathrm{sec}$ prior to the following immunostaining procedures (WATANABE et al., 1988): They were incubated with $5 \%$ non-immune goat serum for blocking at room temperature for $20 \mathrm{~min}$, and then further incubated with the following first antibodies at $4^{\circ} \mathrm{C}$ for $12 \mathrm{~h}$ : anti-oLH $\beta$ (diluted 1: 100 for osmicated samples and 1: 500 for non-osmicated samples), and anti-rCgA (diluted 1:200), or anti-rSgII (diluted 1:200). They were then treated with gold-labeled goat anti-rabbit IgG for $1 \mathrm{~h}$ at room temperature (gold particles of 15 $\mathrm{nm}$ or $8 \mathrm{~nm}$ in diameter); the size adjustment and labeling of colloidal gold particles were performed according to the method by SLOT and GEUZE (1985). Between each step, the grids were washed in $0.02 \mathrm{M}$

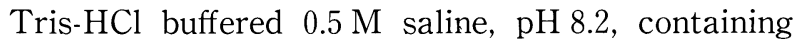
$0.1 \%$ BSA. For double immunostaining, the two-face technique by BENDAYAN (1982) was applied (sizes of the gold particles: $8 \mathrm{~nm}$ and $15 \mathrm{~nm}$ ). Following the immunoreactions, the sections were contrasted with saturated aqueous solutions of uranyl acetate and lead citrate, and examined with a Hitachi (Tokyo, Japan) H-7100 electron microscope.

\section{Morphometry}

After sections of osmicated samples were immunostained with anti-oLH $\beta$ antiserum, cytoplasmic areas of pituitary gonadotropes of female and male were randomly photographed at a magnification of $\times 12,000$ $(n=18$ per each sampling time for female samples and $n=36$ for male samples). The profile sizes of the secretory granules were measured with NIH Image software (written by W. RASBAND, National Institutes of Health, USA), and the results were statistically analyzed with KaleidaGraph ${ }^{\mathrm{TM}}$ software (Synergy Software, PA).

\section{RESULTS}

\section{Changes in plasma concentrations of gonado- tropins during the 4-day rat estrous cycle}

It is well known that concentrations of gonadotropins in the blood plasma of female rats changes over a four-day cycle. To confirm the cyclicity of the female rats used in the present study, the plasma concentrations of LH and FSH were measured by radioimmunoassay.

As shown in Figure 1, the plasma LH concentration of female rats maintained the basal level from the early morning of diestrus $\left(\mathrm{DII}_{0800}\right)$ to the late afternoon of proestrus $\left(\mathrm{P}_{1600}\right)$. The LH concentration then 
was markedly elevated at the early evening of proestrus $\left(\mathrm{P}_{1800}\right)$, and returned again to the basal level by the midnight between the days of proestrus and estrus $\left(\mathrm{E}_{0000}\right)$. This transient elevation of the $\mathrm{LH}$ concentration corresponded to the LH-surge, an explosive release of $\mathrm{LH}$ from gonadotropes in the anterior pituitary just prior to ovulation.

The plasma FSH concentration of the rats also fluctuated with a four-day duration. The concentration of plasma FSH peaked at the evening of proestrus $\left(\mathrm{P}_{2000}\right)$, slightly after the time period of the maximal concentration of plasma $\mathrm{LH}$, and the elevated level of plasma FSH lasted till the early morning of estrus $\left(E_{0800}\right)$. This prolonged elevation of the plasma FSH level was consistent with previous findings by other researchers (BUTCHER et al., 1974; ELIAS and BLAKE, 1981; DEPAOLO and CHAPPEL, 1986).

Judging from these variations in plasma gonadotropin levels, it was confirmed that the cyclicity of the female rats was well synchronized under the present housing conditions.

\section{Expression of $\mathrm{CgA}$ and $\mathrm{SgII}$ in female rat pituitary}

To examine whether the expression and storage levels of $\mathrm{CgA}$ and SgII in pituitary glands of female rats are different from those of male rats, northern blot and immunoblot analyses were performed in pituitary and adrenal samples.

As shown in Figure 2, the mRNA level of $\mathrm{CgA}$ was significantly lower in the pituitary gland of female rats than in that of male rats, while no clear-cut difference was detected in the mRNA levels between the adrenal glands of female and male rats. In contrast to the expression level of $\mathrm{CgA}$ in the pituitary, the mRNA levels of SgII showed no sex-related differences either in the pituitary or adrenal glands.

Immunoblot analyses revealed that protein concentrations of $\mathrm{CgA}$ were apparently less in female than in male pituitary glands, while those of $\mathrm{CgA}$ in the adrenals showed no sex-related difference (Fig.3). No obvious difference was discerned in the amounts of SgII between male and female animals in either the pituitary or adrenal glands.

\section{Intracellular localization of $\mathrm{CgA}$ and $\mathrm{SgII}$ in female rat gonadotropes}

\section{Light microscopy}

Differences in immunoreactivity for $\mathrm{CgA}$ and SgII in gonadotropes were analyzed between male and female animals, using serial semithin sections of the anterior pituitary (Figs. 4, 5). Immunoreactivities for

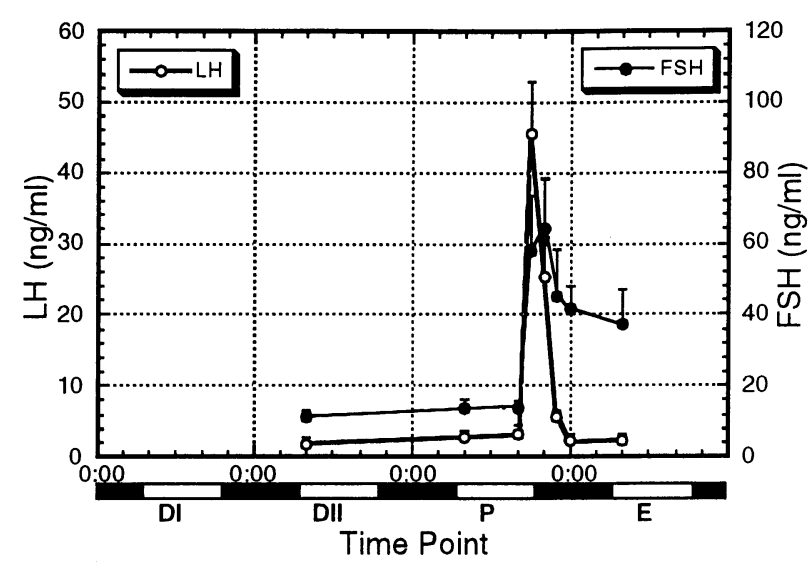

Fig. 1. Changes in the concentrations of LH (open circles) and FSH (closed circles) in blood plasma during the estrous cycle of female rats. Values are the means of five rats per each time point (Bars: + standard error of mean). The plasma LH concentrations of female rats peak at the early evening of proestrus $\left(\mathrm{P}_{1800}\right)$, and return promptly to the basal level by the midnight between the days of proestrus and estrus $\left(\mathrm{E}_{0000}\right)$. The plasma FSH concentrations also begin to rise at the early evening of proestrus but peak slightly later than those of plasma LH (at $\left.\mathrm{P}_{2000}\right)$. The elevation of plasma FSH persists till the early morning of estrus $\left(\mathrm{E}_{0800}\right)$.

$\mathrm{LH}$ and SgII were fine-granular and similarly intense in both male and female gonadotropes (Figs. 4a, c, 5a, c). Granular immunodeposits for CgA were coarser and less intense in both the male and female cells than those for SgII (Figs. 4b, 5b). Moreover, some cells in female rats showed only faint or weak granular immunoreactivity for CgA (Fig. 5b).

\section{Size of secretory granules within male and female gonadotropes}

The existence of prominent sex-related differences in the composition and appearance of secretory granules in gonadotropes is well known (CHILDS, 1986; Kurosumi et al., 1991; TOUGARD and TIXIERVIDAL, 1994). Immunocytochemical analysis clearly demonstrated that typical gonadotropes of male rats contained two distinct subsets of secretory granulelarge-sized ones with moderate electron density, and small-sized ones with high electron density (Fig. 6a) -whereas those of female rats appeared uniformly small in size (Fig. 6b). Using immunocytochemically labeled gonadotropes, we morphometrically analyzed the profile size distribution of secretory granules, which confirmed that the mean profile diameters of 


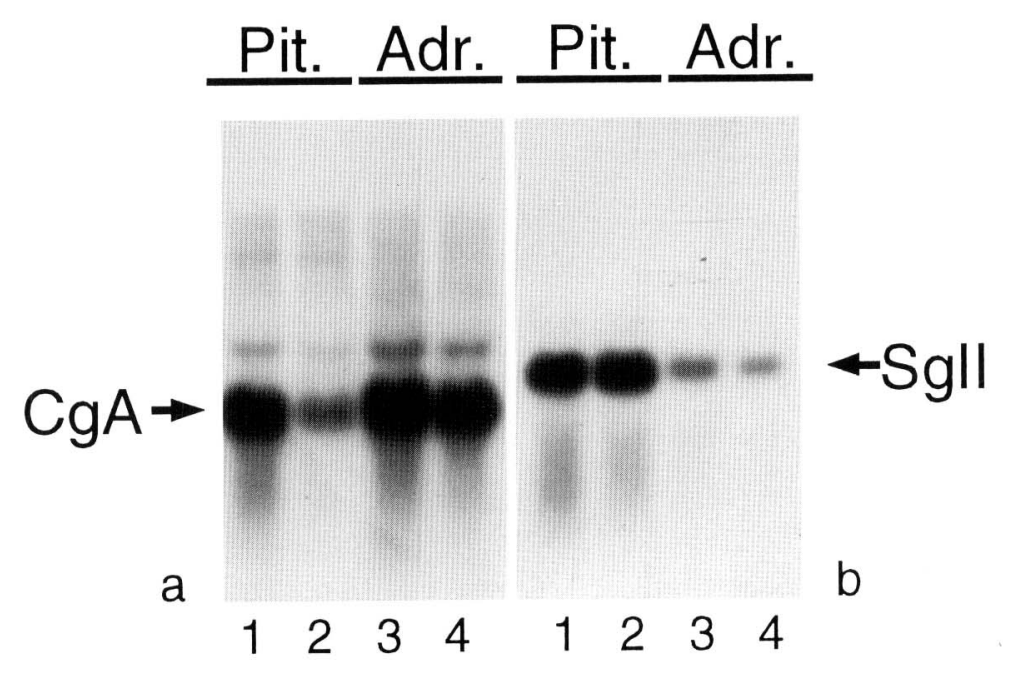

Fig. 2. Northern blot analyses. Equal amounts of total RNA (10 $\mu \mathrm{g} /$ lane) extracted from the pituitaries and adrenals were separated by $1.5 \%$ agarose gel electrophoresis. The blots were hybridized with digoxigenin-labeled $\operatorname{rCgA}(\mathbf{a})$ or $\mathrm{rSgII}(\mathbf{b})$ antisense riboprobes, respectively. Lane 1: male rat pituitary; lane 2: female rat pituitary; lane 3: male rat adrenal; lane 4: female rat adrenal. The expression of $\mathrm{CgA}$ in the female rat pituitary (lane 2 in a) is apparently lower than that in male rat pituitary (lane 1 in a).

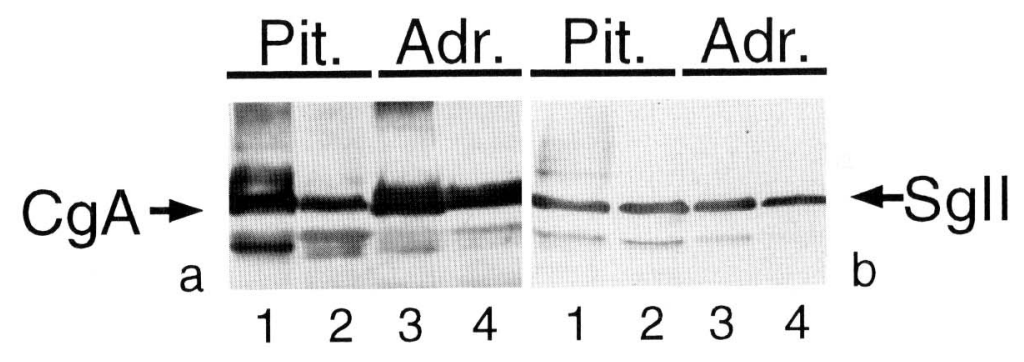

Fig. 3. Immunoblot analyses of $\mathrm{CgA}$ (a) and $\mathrm{SgII}$ (b). Lane 1: male rat pituitary; lane 2: female rat pituitary; lane 3: male rat adrenal; lane 4: female rat adrenal. The protein concentrations in extracts were measured by Lowry's method, and equal amounts of proteins ( $75 \mu \mathrm{g} /$ lane) were applied to each lane. Arrows indicate the full length forms of $\mathrm{CgA}$ (a) and $\mathrm{SgII}$ (b). Note that the amount of $\mathrm{CgA}$ in the female rat pituitary (lane 2 in a) is less than that in male rat pituitary (lane 1 in a). Some breakdown products of these granins are also detected below the full length forms. 


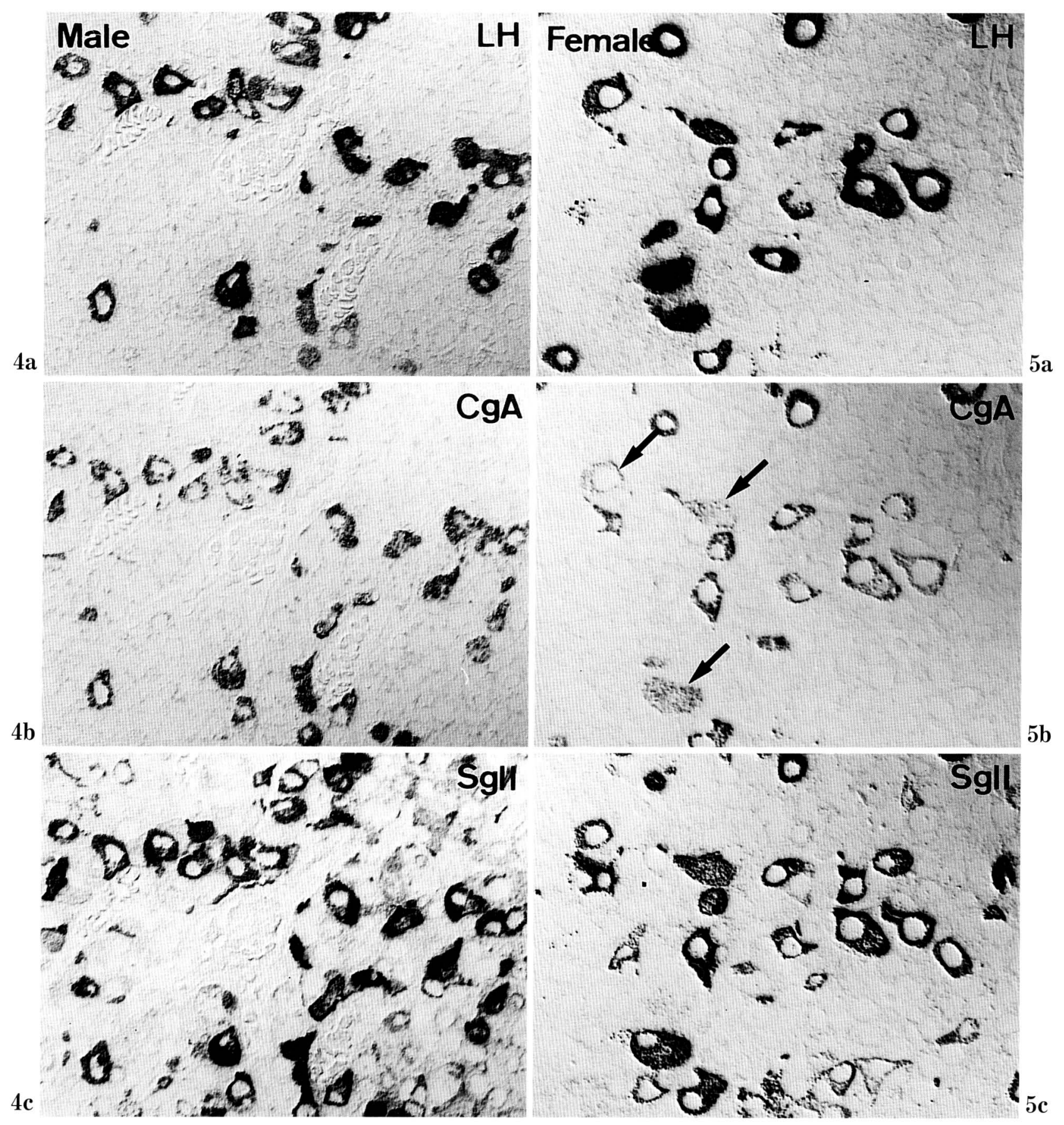

Figs. 4 and 5. Three serial semithin sections of male (Fig. 4) and female (Fig. 5) rat anterior pituitaries, showing immunoreactivity for $\mathrm{LH}(\mathbf{a}), \mathrm{CgA}(\mathbf{b})$, and SgII (c). $\times 500$. Fig. 4. Most gonadotropes in male rat pituitary exhibit immunoreacitivities for two granins, CgA and SgII, concomitantly. The immunoreactivity for $\mathrm{CgA}$ is restricted in gonadotropes, whereas that for SgII is also detected faintly in the other types of endocrine cells. Fig. 5. In female rat pituitary, the immunoreactivity for $\mathrm{Cg} \mathrm{A}$ is also restricted to gonadotropes, although the intensity of staining is weak compared with that in male rat gonadotropes. Arrows indicate the cells which show only faint immunoreactivity for $\mathrm{CgA}$. 

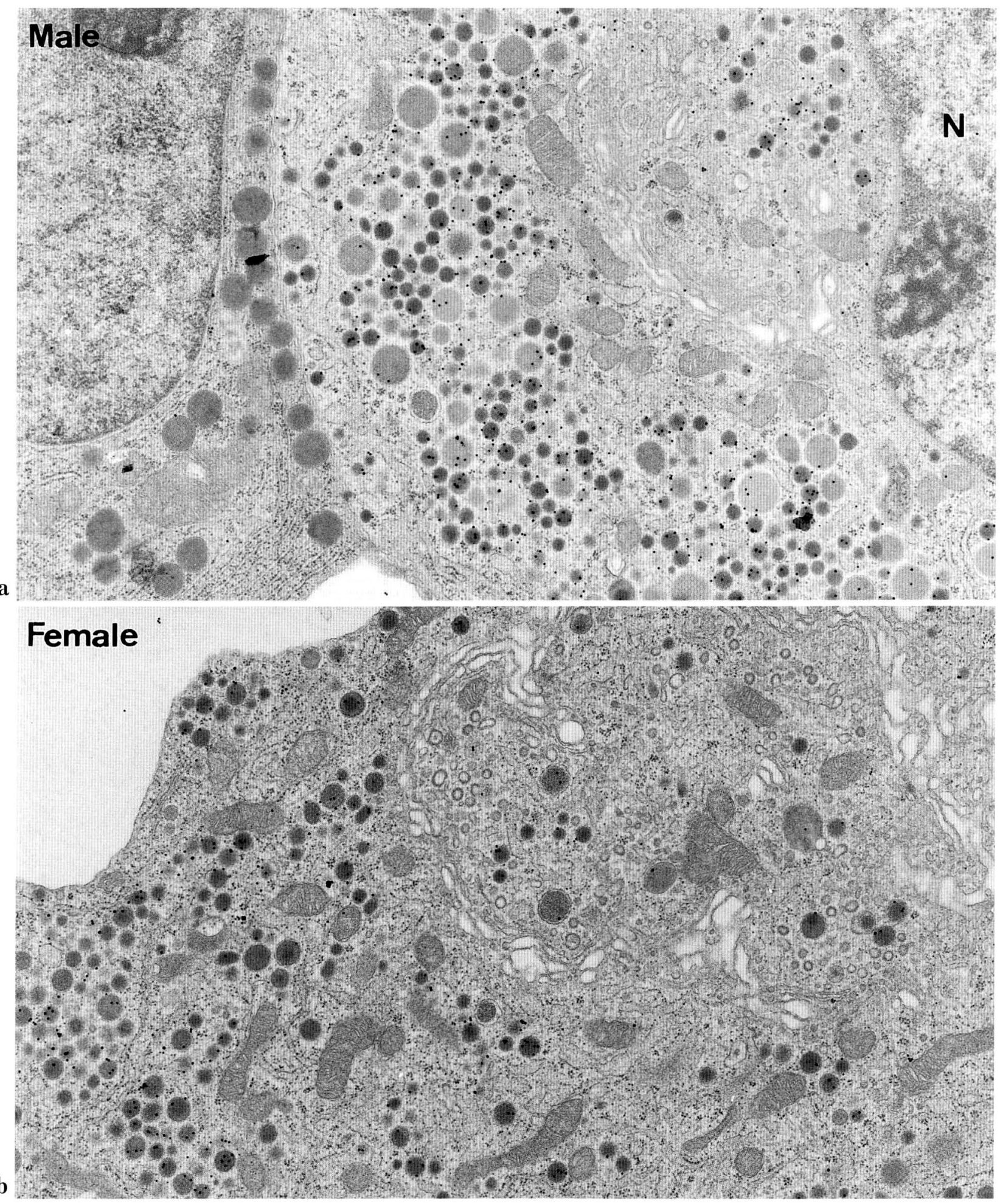

Fig. 6. Electron micrographs of typical male (a) and female (b) rat gonadotropes in the anterior pituitary. Gonadotropes are identified by immunostaining with anti-oLH $\beta$ antiserum $(1: 100$ diluted; size of the gold particles: $15 \mathrm{~nm}$ in diameter). Typical female rat gonadotropes appear to lack large-sized secretory granules, which are regularly observed within typical male rat gonadotropes. $N$ nucleus. $\times 18,000$ 
secretory granules were significantly smaller in female than in male gonadotropes (Fig. 7).

\section{Intracellular localization of $\mathrm{CgA}$ and $\mathrm{SgII}$}

Pituitary ultrathin sections sampled at various time points during estrous cycle were immunostained with anti-rCgA and rSgII antisera (Figs. 8, 9).

In female gonadotropes during diestrus and proestrus, immunogold particles indicating SgII intensely labeled secretory granules, while those showing CgA were associated with only a limited number of secretory granules (Fig. 8). Immunogold labeling of $\mathrm{CgA}$ was mostly detected in the peripheral part of SgII-immunopositive small-sized secretory granules (Fig. 8a, b, d). Moreover, secretory granules labeled solely with immunogold particles indicating $\operatorname{CgA}$ were only rarely observed in these gonadotropes.

On the other hand, immunoreactivity for $\mathrm{CgA}$ was more prominent in gonadotropes sampled shortly after LH-surge $\left(\mathrm{E}_{0000}\right.$ and $\left.\mathrm{E}_{0800}\right)$; secretory granules labeled with immunogold particles indicating $\mathrm{CgA}$ were more frequently discerned in the cytoplasm, and mostly co-labeled with those indicating SgII (Fig. 9a, b, d). Typical secretory granules co-labeled for SgII and $\operatorname{CgA}$ were slightly larger in size than secretory granules immunostained only for SgII. The central core region of double-immunostained granules was immunopositive only for SgII, showing a similar electron density and size of secretory granules immunostained only for SgII, while the peripheral less electron dense area of the granules was immunostained by anti-rCgA only (Fig. 9d). Secretory granules immunostained only with anti-rCgA also appeared during these estrous phases, but these $\mathrm{CgA}$ immunopositive secretory granules were not as large as those observed in typical male rat gonadotropes (Fig 9a, b, d).

\section{DISCUSSION}

Chromogranins and secretogranins are known as acidic secretory proteins which are specifically distributed in secretory granules of neuroendocrine cells (for reviews see SIMON and AUNIS, 1989; HUTTNER et al., 1991; WINKLER and FISCHER-COLBRIE, 1992). Physiological roles of these proteins are still arguable, but their characteristic localization has widely been utilized as diagnostic markers for neuronal or endocrine tissue-derived tumors (for review see WIEDENMANN and HUTTNER, 1989) or tracers for the regulated secretory pathway to investigate the biogenesis of secretory granules (TOOZE and HUTTNER, 1990; TOOZE et al., 1991; HINKLE et al., 1992;
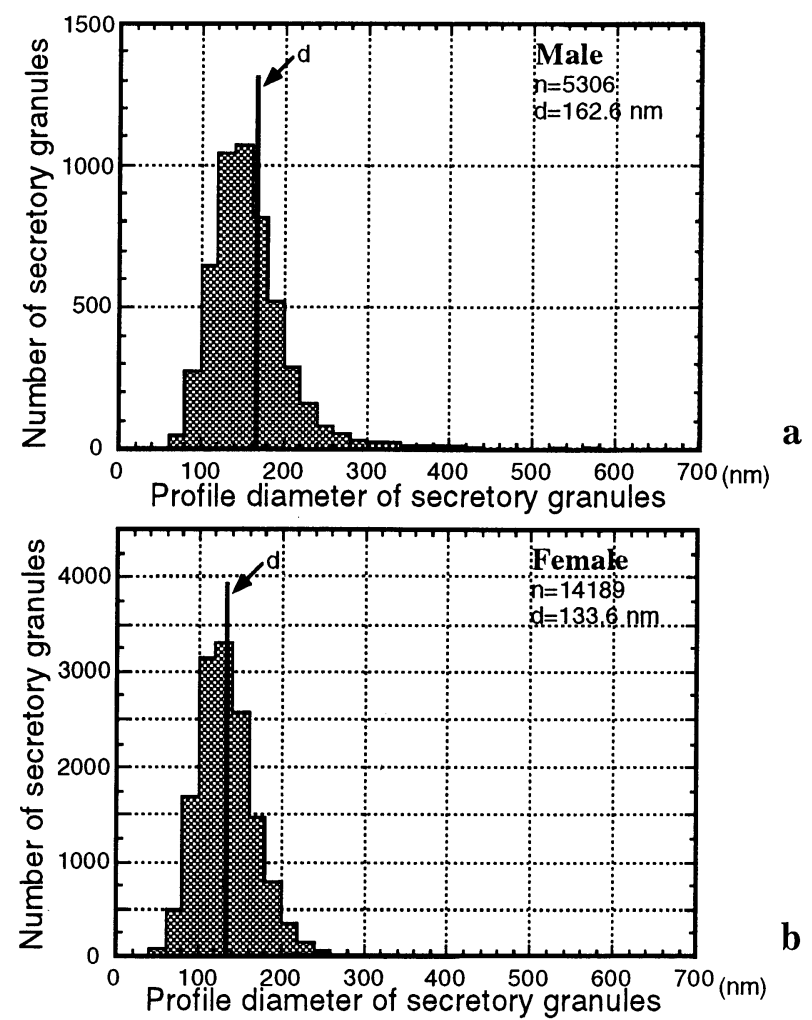

Fig. 7. Histograms of profile size distribution of secretory granules in male (a) and female (b) rat gonadotropes. The mean profile size of secretory granules of female rat gonadotropes $(133.6 \pm 0.3 \mathrm{nim} ;$ mean $\pm \mathrm{SEM})$ is significantly smaller than that of male rat gonadotropes $(162.6 \pm 0.8 \mathrm{~nm})$.

THOMPSON et al., 1992; for review see also SCAMMELL, 1993).

Our previous studies have clearly demonstrated that two representative granins, $\mathrm{CgA}$ and $\mathrm{SgII}$, are useful markers to discern the matrices of large- and small-sized secretory granules in male rat gonadotropes (WATANABE et al., 1991, 1993; JEZIOROWSKI et al., 1997). The present study further demonstrated that the intracellular localization of $\operatorname{CgA}$ and SgII within female rat gonadotropes provided a clue to classify secretory granules with a relatively uniform appearance. In the following sections, we will discuss (1) what the substantial repertoire of secretory granules is within rat gonadotropes, and (2) how these heterogeneous subsets of secretory granules can possibly participate in the differential secretion of gonadotropins. 

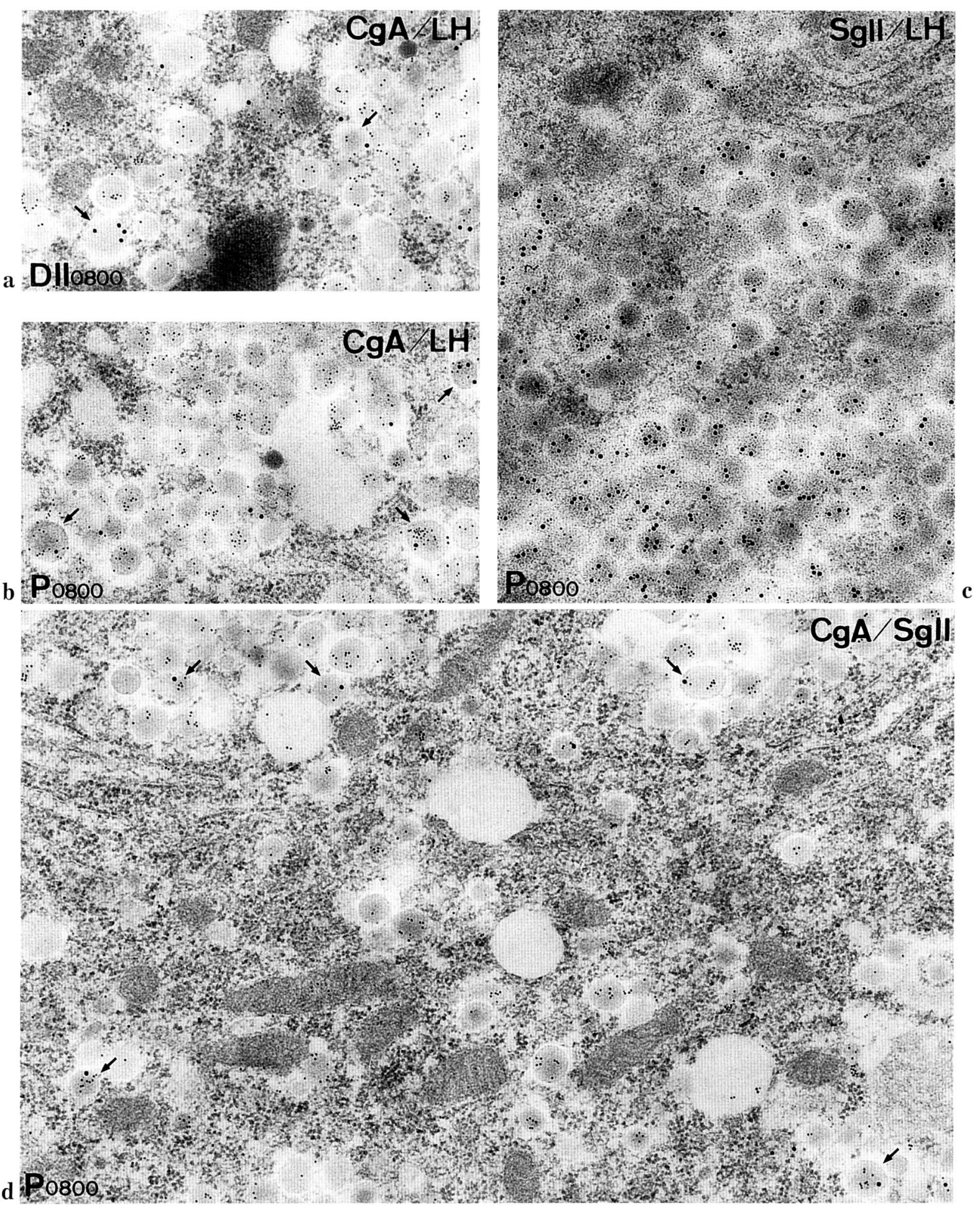

Fig. 8. Immunocytochemical localization of $\mathrm{CgA}$ and $\mathrm{SgII}$ in the typical female gonadotropes sampled during diestrus and proestrus: sampled at $\mathrm{DII}_{0800}(\mathbf{a})$, and $\mathrm{P}_{0800}(\mathbf{b}, \mathbf{c}, \mathbf{d})$. Immunogold particles indicating CgA (size of the gold particles: $15 \mathrm{~nm}$ ) are restricted in the peripheral region of only a limited number of secretory granules (arrows) (a, b), whereas those indicating SgII $(15 \mathrm{~nm})$ are distributed over most small-sized secretory granules $(\mathbf{c})$. Gonadotropes in a-c are identified by immunostaining with anti-oLH $\beta$ antiserum (size of the gold particles: 8 $\mathrm{nm})$. Double immunostaining for CgA $(15 \mathrm{~nm})$ and SgII $(8 \mathrm{~nm})$ confirms their intragranular localizations within typical female rat gonadotropes $(\mathbf{d}) . \times 34,000$ 

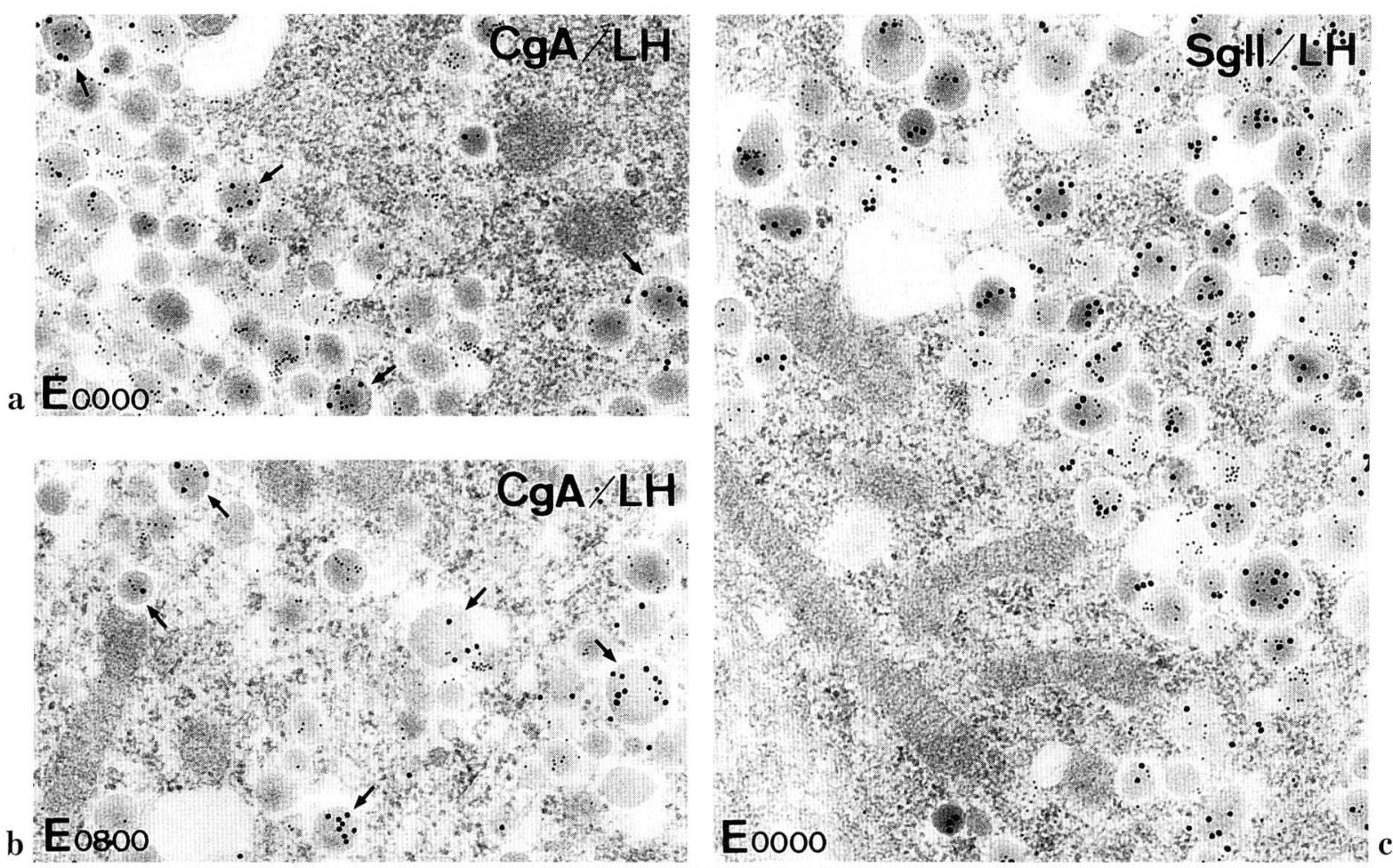

E0000

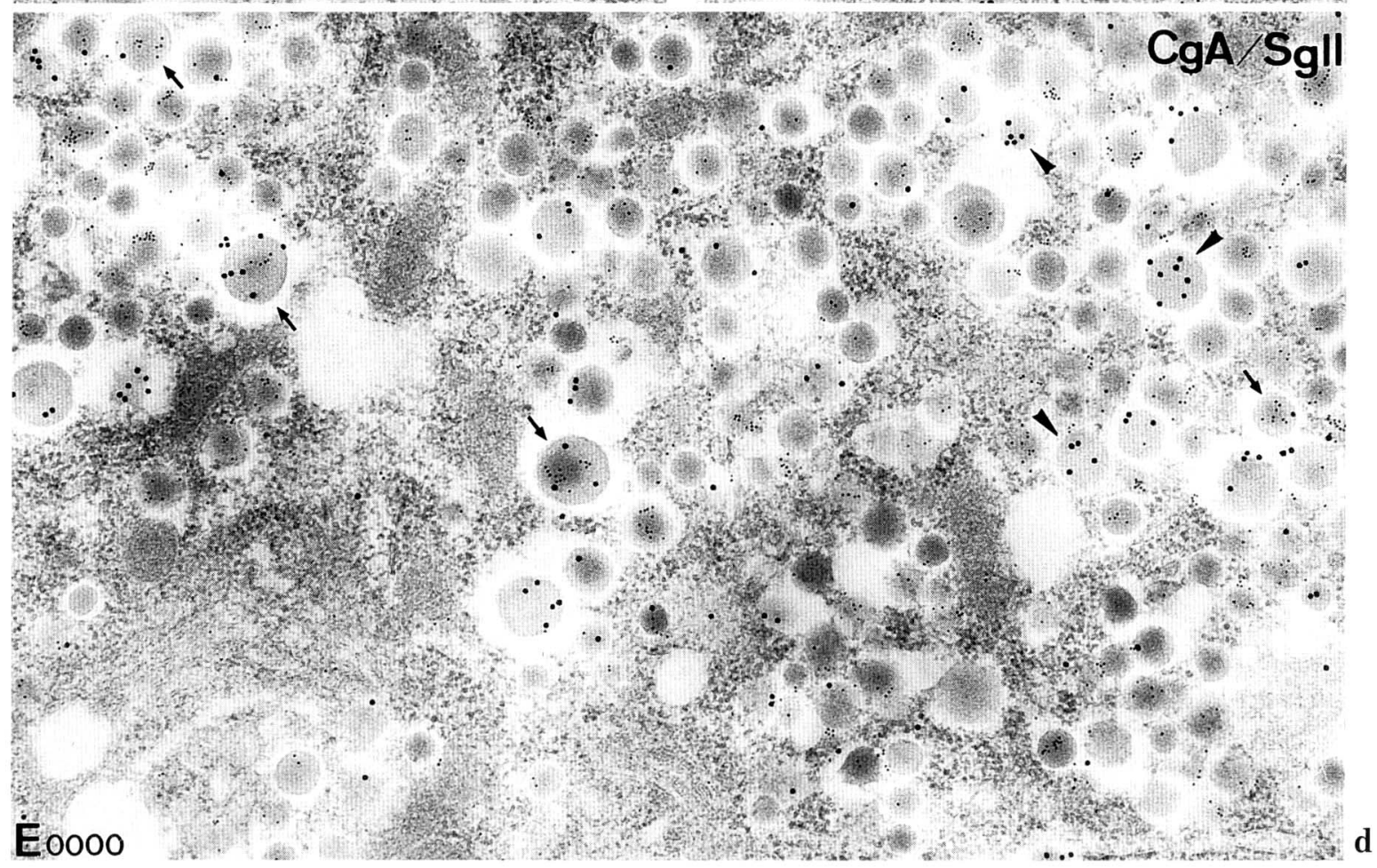

Fig. 9. Immunocytochemical localization of $\mathrm{CgA}$ and $\mathrm{SgII}$ in the female rat gonadotropes after the $\mathrm{LH}$ surge; sampled at $\mathrm{E}_{0000}(\mathbf{a}, \mathbf{c}, \mathbf{e})$, and $\mathrm{E}_{0800}(\mathbf{b})$. Immunogold particles indicating $\mathrm{CgA}(15 \mathrm{~nm})$ are more densely distributed on secretory granules than before the LH surge $(\mathbf{a}, \mathbf{b})$. Immunogold particles indicating SgII $(15 \mathrm{~nm})$ are constantly observed on small-sized secretory granules (c). Gonadotropes in a-c are identified by immunostaining with anti-oLH $\beta$ antiserum $(8 \mathrm{~nm})$. Double immunostaining for $\mathrm{CgA}(15 \mathrm{~nm})$ and $\mathrm{SgII}(8 \mathrm{~nm})$ clearly demonstrates that there are secretory granules labeled by immunogold particles indicating either $\mathrm{CgA}$ (arrowheads) or both $\mathrm{CgA}$ and SgII (arrows) (d). $\times 34,000$ 


\section{Repertoire of secretory granules in male and female rat gonadotropes}

It has widely been accepted that there are at least two major subtypes of gonadotropes, although they have been arbitrarily designated by individual researchers (for review see TOUGARD and TIXIERVIDAL, 1994). One of these is the gonadotrope predominantly present in the male rat pituitary, and the other is that in the female rat pituitary. Typical male rat gonadotropes are known to exhibit two ultrastructurally different subsets of secretory granules, large- and small-sized ones. Our previous studies have demonstrated that the intracellular localization of $\mathrm{CgA}$ and SgII corresponds directly to each type of secretory granule within these cells (WATANABE et al., 1991; JEZIOROWSKI et al., 1997).

It has been shown that typical female rat gonadotropes exhibit only small-sized secretory granules (CHILDS, 1986; KUROSUMI et al., 1991; TOUGARD and TIXIER-VIDAL, 1994). The present immunocytochemical study, however, demonstrated that there is also heterogeneity in the distribution of $\mathrm{CgA}$ and $\mathrm{SgII}$ in female gonadotropes. Considering the intragranular localization of $\mathrm{CgA}$ and $\mathrm{SgII}$, secretory granules in gonadotropes can be commonly divided into the following three types: CgA-positive, SgII-positive, and $\mathrm{CgA} / \mathrm{SgII}$-double positive secretory granules. Among these three types of secretoy granules, SgIIpositive granules with a constant size of ca. $200 \mathrm{~nm}$ in diameter appear universally and occupy the majority in both male and female gonadotropes. In contrast to SgII-positive ones, the appearance and size of $\mathrm{CgA}$ positive secretory granules seem to vary with the functional state of gonadotropes. As stated above, CgA-positive granules are prominent in typical male rat gonadotropes since they are larger in size than SgII-positive granules. CgA-positive granules in female gonadotropes, however, are impossible to be morphologically distinguished from the SgII-positive ones since they are fewer in number and smaller in size than those in male gonadotropes. Present northern blot and immunoblot analyses indicate that these sex-related differences in the size and appearance of this type of granule correspond to the expression and storage levels of $\mathrm{CgA}$ in the pituitary.

In addition to these two types of secretory granules which contain either SgII or $\operatorname{CgA}$, there exists the third type of secretory granule showing the immunoreactivity of both granins. We have previously found this type granule in the stimulated male rat gonadotropes, and designated it as 'the intermediate type' (WATANABE et al., 1993). This granule consists of a high electron-dense core occupied with SgII and a peripherally less dense area with $\mathrm{CgA}$. This characteristic feature of the intermediate granules was also seen in female gonadotropes, although the latter granules were much smaller in size than the former granules. Moreover, similar to the intermediate granules in male gonadotropes, the peripheral $\mathrm{CgA}$-im munopositive area determined the size of the granules in the female cells since the core region immunoreactive for SgII was likely to be constantly smallsized. Thus, the size of the intermediate granules seems to vary also corresponding to the expression level of $\mathrm{CgA}$ as well as $\mathrm{CgA}$-single positive granules.

Based on these observations on the repertoire of secretory granules of gonadotropes in male and female gonadotropes, ultrastructures of gonadotropes are likely to be characterized by the sizes and proportions of the three types of secretory granules, which are closely related to the expression and storage levels of $\mathrm{CgA}$ and SgII. These findings suggest that the factor(s) which regulate the expression and storage levels of $\mathrm{CgA}$ and SgII will also affect the morphological features of each gonadotrope. Steroids are most likely to affect the ultrastructure of gonadotropes through the regulation of granin expression in the pituitary gland (GRINO et al., 1989; ANOUAR et al., 1991; FISCHER-COLBRIE et al., 1992; LLOYD et al., 1992).

\section{Possible functional roles of heterogeneous secretory granules within gonadotropes}

Two gonadotropins, $\mathrm{LH}$ and FSH, are known to be secreted occasionally in non-parallel manner. As demonstrated also in the present study, the plasma concentrations of $\mathrm{LH}$ and $\mathrm{FSH}$ did not always vary in parallel during the estrous cycle of female rats (see also BUTCHER et al., 1974; ELIAS and BLAKE, 1981; DEPAOLO and CHAPPEL, 1986). More direct evidence for the non-parallel release of gonadotropins has been elucidated from studies on the effects of activin(s) and inhibin(s) on gonadotropes; they stimulate or suppress only the FSH release from gonadotropes, and not the LH release (RIVIER et al., 1991; for reviews see also VALE et al., 1990; FARNWORTH, 1995). CHILDS (1995) has recently proposed that individual gonadotropes can transform into various subtypes of gonadotropes which synthesize and secrete two gonadotropins differently, according to the functional state required. However, little is known about details of the mechanism, particularly from a structural basis, which enables the separative release of different gonadotropins.

It has been suggested that $\mathrm{LH}$ and FSH may be 
localized to different secretory granules within individual gonadotropes under certain physiological conditions (CHILDS et al., 1987; PAYETTE et al., 1987). Especially, the immunoreactivity for FSH has been demonstrated only in large-sized secretory granules of typical male rat gonadotropes (INOUE and KUROSUMI, 1984; WATANABE et al., 1991). However, it is also evident that gonadotropins do not seem to be stably expressed in gonadotropes under various physiological and experimental conditions. Therefore, when the localization of these hormones, especially $\mathrm{FSH}$, is examined by immunocytochemistry, it is often difficult to decide the exact localization even if the secretory granules remain unaltered within the gonadotropes.

In contrast to gonadotropins, the immunoreactivity for $\mathrm{CgA}$ and $\mathrm{SgII}$ can be detected in gonadotropes under most physiological and experimental conditions. As stated above, the expression levels of each granin are closely associated with the size and appearance of corresponding subtypes of secretory granules. It is well known that granins can self-aggregate under low $\mathrm{pH}$ and high calcium conditions (for reviews see SIMON and AUNIS, 1989; HUTTNER et al., 1991; WINKLER and FISCHER-COLBRIE, 1992). More recently, a biochemical study has demonstrated that LH co-aggregates with granins but does not show self-aggregation even under low $\mathrm{pH}$ and high calcium conditions (COLOMER et al., 1996). These findings suggest that $\mathrm{CgA}$ and SgII play more essential roles in forming each type of secretory granule, indicating that these granin proteins are more appropriate markers for immunocytochemistry showing the regulated secretory pathways in these cells than gonadotropins.

It should be also noted that the appearance of $\mathrm{CgA}$-positive and intermediate granules in female gonadotropes is prominent shortly after LH-surge, corresponding to the phase of the high plasma FSH concentration (Fig. 1). As stated above, immunocytochemical studies have demonstrated the colocalization of $\mathrm{CgA}$ and FSH in the large-sized secretory granules of typical male rat gonadotropes. These findings suggest that FSH may be associated with CgA-positive granules or matrices of female gonadotropes, although the results remain indecisive. At present, however, further studies are required to determine whether $\mathrm{CgA}$ and $\mathrm{SgII}$ can specifically associate with each gonadotropin, and how the formation and release of these different subsets of secretory granules are regulated by various factors or stimuli.

Summing up, the present study demonstrated that pituitary gonadotropes of both male and female rats potentially possess three different subsets of secretory granules: SgII-positive, CgA-positive, and intermediate ones. Moreover, the size and appearance of these secretory granules are closely associated with the sex-related differences in expression and storage levels of corresponding granins. These results suggest the possibility that the granins play essential roles in the formation of these three types of secretory granules, and that the dynamic changes in the size and composition of each type of secretory granule in female gonadotropes contribute to the separative secretion of the two distinct gonadotropins during the estrous cycle.

Acknowledgments. For a generous supply of antisera against rat $\mathrm{CgA}$ and SgII, we are indebted to Dr. $\mathrm{H}$. WINKLER and Dr. R. FISCHER-ColbRIE (Department of Pharmacology, University of Innsbruck, Austria). We thank Dr. K. Wakabayashi (Gumma University, Japan) for the anti-ovine $\mathrm{LH} \beta$ antiserum. We are grateful to Dr. K. NAKAYAma and Dr. M. Hosaka (Gene Experiment Center, University of Tsukuba) for helpful suggestions on the molecular biological methods. We also thank Mrs. C. HöPfel (Hannover), Mrs. J. SAKamoto (Tsukuba), and Mr. N. KomoRI (Osaka) for expert technical assistance.

\section{REFERENCES}

Anouar, Y., T. Benié, M. DeMonti, R. Counis and J. DUVAL: Estradiol negatively regulates secretogranin II and chromogranin A messenger ribonucleic acid levels in the female rat pituitary but not in the adrenal. Endocrinology 129: 2393-2399 (1991).

Bargsten, G. and D. Grube: Serotonin storage and chromogranins: an experimental study in rat gastric endocrine cells. J. Histochem. Cytochem. 40: 1147-1155 (1992).

Bendayan, M.: Double immunocytochemical labeling applying the protein A-gold technique. J. Histochem. Cytochem. 30: 81-85 (1982).

Butcher, R. L., W. E. Collins and N. W. Fugo: Plasma concentration of $\mathrm{LH}, \mathrm{FSH}$, prolactin, progesterone and estradiol-17 $\beta$ throughout the 4-day estrous cycle of the rat. Endocrinology 94: 1704-1708 (1974).

Childs, G. V.: Division of labor among gonadotropes. Vitam. Horm. 50: 215-286 (1995).

-: Functional ultrastructure of gonadotropes; a review. In: (ed. by) D. GANTEN and D. W. PfAFF: Morphology of hypothalamus and its connections. Springer-Verlag, New York, 1986 (p. 49-97).

Childs, G. V., J. M. Lloyd, G. Unabia, S. D. Gharib, M. E. WiERMAN and W. W. ChIN : Detection of luteinizing hormone beta messenger ribonucleic acid (RNA) in individual gonadotropes after castration: use of a new in situ hybridization method with a photobiotinylated complementary RNA probe. Mol. Endocrinol. 1: 926932 (1987a). 
Childs, G. V., G. Unabia, R. Tibolt and J. M. Lloyd: Cytological factors that support nonparallel secretion of luteinizing hormone and follicle-stimulating hormone during the estrous cycle. Endocrinology 121: 1801-1813 (1987b).

Chomczynski, P. and N. SACchi: Single-step method of RNA isolation by acid guanidimium thiocyanatephenol-chloroform extraction. Anal. Biochem. 162: 156159 (1987).

Colomer, V., G. A. Kicska and M. J. Rindler: Secretory granule content proteins and the luminal domains of granule membrane proteins aggregate in vitro at mildly acidic pH. J. Biol. Chem. 271: 48-55 (1996).

DePaolo, L. V. and S. C. Chappel: Alterations in the secretion and production of follicle-stimulating hormone precede age-related lengthening of estrous cycles in rats. Endocrinology 118: 1127-1133 (1986).

Elias, K. A. and C. A. Blake: A detailed in vitro characterization of the basal follicle-stimulating hormone and luteinizing hormone secretion rates during the rat fourday estrous cycle. Endocrinolgy 109: 708-713 (1981).

FARNworTh, P. G.: Gonadotrophin secretion revisited. How many ways can FSH leave a gonadotroph? J. Endocrinol. 145: 387-395 (1995).

Fischer-Colbrie, R., R. Zangerle, I. FrischenschLAGER, A. WEBER and H. WINKLER: Isolation and immunological characterization of a glycoprotein from adrenal chromaffin granules. J. Neurochem. 42: 10081016 (1984).

Fischer-Colbrie, R., K. W. Schmid, S. K. Mahata, M. Mahata, A. Laslop and J. W. Bauer: Sex-related differences in chromogranin $\mathrm{A}$, chromogranin $\mathrm{B}$ and secretogranin II gene expression in rat pituitary. J. Neuroendocrinol. 4: 125-130 (1992).

Gerdes, H. H., E. Phillips and W. B. Huttner: The primary structure of rat secretogranin II deduced from a cDNA sequence. Nucl. Acids Res. 16: 11811 (1988).

Grino, M., T. Wohlfarter, R. Fischer-Colbrie and L. E. EIDEN : Chromogranin A messenger RNA expression in the rat anterior pituitary is permissively regulated by the adrenal gland. Neuroendocrinology 49: 107-110 (1989).

Grube, D. and Y. Kusumoto: Serial semithin sections in immunohistochemistry: techniques and applications. Arch. Histol. Jap. 49: 391-410 (1986).

GRube, D. and S. Yoshie: Immunohistochemistry of chromogranin $\mathrm{A}$ and $\mathrm{B}$, and secretogranin II in the canine endocrine pancreas. Arch. Histol. Cytol. 52: 287298 (1989).

Hinkle, P. M., J. G. Scammell and E. D. Shanshala II: Prolactin and secretogranin-II, a marker for the regulated pathway, are secreted in parallel by pituitary GH4C1 cells. Endocrinology 130: 3503-3511 (1992).

Huttner, W. B., H. H. Gerdes and P. Rosa: The granin (chromogranin/secretogranin) family. Trends Biochem. Sci. 16: 27-30 (1991).

Iacangelo, A., H. OKayama and L. E. Eiden: Primary structure of rat chromogranin A and distribution of its mRNA. FEBS Lett. 227: 115-121 (1988).
Inoue, K. and K. Kurosumi: U1trastructural immunocytochemical localization of LH and FSH in the pituitary of the untreated male rat. Cell Tiss. Res. 235: 77-83 (1984).

Jezionowski, T., T. Watanabe, G. Bargsten and D. GRUBE: Heterogeneity of pituitary gonadotrope cells in male rats. Arch. Histol. Cytol. 60: 355-370 (1997).

Kurosumi, K., H. Ozawa, K. Akiyama and T. Senshu: Immunoelectron microscopic studies of gonadotrophs in the male and female rat anterior pituitaries, with special reference to their changes with aging. Arch. Histol. Cytol. 54: 559-571 (1991).

LiU, Y. C., Y. Kato, K. Inoue, S. Tanaka and K. KURosUmI: Co-localization of $\mathrm{LH} \beta$ and $\mathrm{FSH} \beta$ mRNAs in the porcine anterior pituitary by in situ hybridization with biotinylated probes. Biochem. Biophys. Res. Commun. 154: 80-84 (1988).

LloYd, J. M. and G. V. ChILDs: Differential storage and release of luteinizing hormone and follicle-releasing hormone from individual gonadotropes separated by centrifugal elutriation. Endocrinology 122: 1282-1290 (1988).

Lloyd, R. V., K. Hawkins, L. Jin, E. Kulig and K. FIELDS: Chromogranin A, chromogranin B and secretogranin II mRNAs in the pituitary and adrenal glands of various mammals. Regulation of chromogranin $\mathrm{A}$, chromogranin B and secretogranin II mRNA levels by estrogen. Lab. Invest. 67: 394-404 (1992).

Payette, R. F., M. D. Gershon and E. A. Nunez: Two types of secretory granules in gonadotrophs: discrimination by the simultaneous EM immunocytochemical localization of serotonin and $\beta$-follicle stimulating hormone. Anat. Rec. 219: 394-401 (1987)

Rivier, C., R. Schwall, A. Mason, L. Burton, J. VAUGHAN and W. VALE: Effect of recombinant inhibin on luteinizing hormone and follicle-stimulating hormone secretion in the rat. Endocrinology 128: 1548-1554 (1991).

Sambrook, J., E. F. Fritsch and T. Maniatis: Molecular cloning: A laboratory manual. Cold Spring Harbor Laboratory Press, New York, 1989.

ScAmMELL, J.: Granins: markers of the regulated secretory pathway. Trends Endocrinol. Metab. 4: 14-18 (1993).

Simon, J. P. and D. Aunis: Biochemistry of the chromogranin A protein family. Biochem. J. 262: 1-13 (1989).

Slot, J. W. and H. J. Geuze: A new method of preparing gold probes for multiple-labeling cytochemistry. Eur. J. Cell Biol. 38: 87-93 (1985).

Thompson, M. E., W. E. Zimmer, A. L. Haynes, D. L. V ALENTINe, P. S. Forss and J. G. Scammell: Prolactin granulogenesis is associated with increased secretogranin expression and aggregation in the Golgi apparatus of GH4C1 cells. Endocrinology 131: 318-326 (1992).

Tooze, S. A. and W. B. HutTner: Cell-free protein sorting to the regulated and constitutive secretory pathways. Cell 60: 837-847 (1990).

Tooze, S. A., T. Flatmark, J. Tooze and W. B. Hutter: Characterization of the immature secretory granule, an 
intermediate in granule biogenesis. J. Cell Biol. 115: 1491-1503 (1991).

Tougard, C. and A. Tixier-Vidal: Lactotropes and gonadotropes. In: (ed. by) E. KNOBIL and J. D. NeILL: The physiology of reproduction. 2nd ed. Raven Press, New York, 1994 (p. 1711-1747).

Towbin, H., T. Staehelin and J. GoRdon: Electrophoretic transfer of proteins from polyacrylamide gels to nitrocellulose sheets: procedure and some applications. Proc. Nat. Acad. Sci. USA 76: 4350-4354 (1979).

Vale, W., A. Hsueh, C. Rivier and J. Yu: The inhibin/ activin family of hormones and growth factors. In: (ed. by) M. A. SPORN and A. B. ROBERTS: Handbook of experimental pharmacology. Peptide growth factors and their receptors. Springer-Verlag, Heidelberg, 1990 (Vol. 95, part II, p. 211-248)

Watanabe, M., T. Watanabe, Y. Ishit, H. Matsuba, S. Kimura, T. Fujita, E. Kominami, N. Katunuma and Y. UсHIYAмa: Immunocytochemical localization of cathepsins $\mathrm{B}, \mathrm{H}$, and their endogenous inhibitor, cysta$\operatorname{tin} \beta$, in islet endocrine cells of rat pancreas. J. Histochem. Cytochem. 36: 783-791 (1988).

Watanabe, T., Y. Uchiyama and D. Grube: Topology of chromogranin A and secretogranin II in the rat anterior pituitary: potential marker proteins for distinct secretory pathways in gonadotrophs. Histochemistry 96: 285-293 (1991).
W atanabe, T., T. Jeziorowski, W. Wuttke and D. Grube: Secretory granules and granins in hyperstimulated male rat gonadotropes. J. Histochem. Cytochem. 41: 1801-1812 (1993).

Wiedenmann, B. and W. B. Huttner: Synaptophysin and chromogranins/secretogranins-widespread constituents of distinct types of neuroendocrine vesicles and new tools in tumor diagnosis. Virchows Arch. B Cell Pathol. 58: 95-121 (1989).

Winkler, H. and R. Fischer-Colbrie: The chromogranins A and B: the first 25 years and future perspectives. Neuroscience 49: 497-528 (1992).

Dr. Tsuyoshi Watanabe

Department of Cell Biology and Anatomy Osaka University Medical School Yamadaoka 2-2, Suita-City

Osaka, 565-0871 Japan

渡 部剛

565-0871

吹田市山田丘 2-2

大阪大学医学部

解剖学第一講座 